\title{
Estimation of the effect of temperature during dehydration of grass on true digestibility of rumen undergraded dietary protein using rats
}

\author{
Z.M. Kowalski ${ }^{1}$, L. Jarosz ${ }^{2}$, J. Kański' ${ }^{1}$ and B. Kownacki ${ }^{1}$ \\ 1 Department of Animal Nutrition, Agricultural University of Cracow \\ Al. Mickiewicza 24/28, 30-059 Kraków, Poland \\ 2 Department of Animal Nutrition, Agricultural University of Wroctaw \\ Norwida 25, 50-375 Wroclaw, Poland
}

(Received 26 October 1992; accepted 14 December 1992)

\begin{abstract}
The aim of this study was to determine the effect of different dryer outflow temperatures $\left(123^{\circ} \mathrm{vs}\right.$. $153^{\circ} \mathrm{C}$ ) imposed during dehydration of grass, on the digestibility of rumen undegraded dietary protein (UDP) in rats. UDP was the residue obtained after incubation of dehydrated grasses (DG123 and DG153) in the rumen of sheep for 12 hours. The protein in the diets for rats was derived from egg white $(70 \%)$ and UDP $(30 \%)$.

Compared to DG123, DG153 had a higher proportion of ADIN in total N $(10.46$ vs. $23.91 \%)$ as well as significantly higher ruminal degradability $(39.8$ vs. $34.6 ; \mathrm{P}<0.01)$. In the trial with rats, both apparent and true digestibility of UDP from DG $153(88.0$ and $92.6 \%)$ were significantly higher than from DG123 $\left(85.7\right.$ and $90.5 \%$ ). This may suggest that a temperature of $153^{\circ} \mathrm{C}$ can protect protein against degradation in the rumen without any unfavourable effect on intestinal digestibility.
\end{abstract}

KEY WORDS: protein, heating, rumen, digestion, rat

\section{INTRODUCTION}

The new protein evaluation systems assume that protein requirements for ruminants are met from microbial protein and undegraded dietary protein (UDP) digested in the small intestine. Values between 0.80 and 0.85 are generally accepted as the true digestibility of microbial amino acids (ARC, 1984; NKJ, 1985; Vérité et al., 1989). On the other hand, it has been demonstrated lately that the true digestibility of UDP is not a constant value (De Boer et al., 1987; Hvelplund et al., 1992; Peyraud et al., 1988). It can be influenced either by the extent of rumen degradability (Hvelplund et al., 1992) or chemical and heat treatments (Faldet et al, 1992). However, more data are still required.

A few methods are available to assess the intestinal digestibility of UDP but none of them is fully accepted. In vivo methods are too expensive and 
time-consuming. A mobile nylon bag technique, although suitable to screen differences among feeds (De Boer et al., 1987; Hvelplund et al., 1992; Peyraud et al., 1988), still needs standarization.

Based on the similarities of protein digestion in the abomasum and small - intestine in ruminants and in non-ruminants, it may be reasonable to use rats to predict the digestibility of UDP in the intestines. The aim of the present study was to determine the effect of heat treatment during dehydration of grass on the digestibility of UDP in rats.

\section{MATERIAL AND METHODS}

\section{Preparation of UDP}

Two ruminally cannulated rams were used. They were fed a diet consisting of meadow hay $(75 \%)$ and crushed barley grain $(25 \%)$, divided into 2 equal portions.UDP was prepared from dehydrated grasses (DG) with a meadow-grass (Poa L.) as the dominant component, differing by the temperature of the dryer outlow used during their dehydration, i.e. $123^{\circ} \mathrm{C}$ (DG123) and $153^{\circ} \mathrm{C}$ (DG153) (for details see Kowalski et. al., 1992). Ground samples of DG (1.7 mm) were placed in nylon bags and incubated in the rumen for 12 hours. Bags were made of polyester cloth with a pore size of $57 \mu \mathrm{m}$. In order to obtain sufficient amounts of UDP, $18 \times 17 \mathrm{~cm}$ bags and sample size of $21 \mathrm{~g}\left(33 \mathrm{mg}\right.$ of DM/ $\left.\mathrm{cm}^{2}\right)$ were used. Additionally, a $50 \mathrm{~g}$ weight was placed into each bag to prevent its floating in the rumen. Upon recovery from the rumen, residues were mechanically washed, freeze-dried and pooled. Three bags were incubated per animal every day and about $200 \mathrm{~g}$ of freeze-dried residue was collected for each DG. Dry matter and protein degradability in the rumen were estimated using six randomly chosen bags.

\section{Digestibility of UDP in rats}

Eighteen albino rats weighing av. $90 \mathrm{~g}$ were randomly assigned to 3 groups fed isonitrogenous diets containing $10 \%$ of crude protein and $16 \%$ crude fibre. The composition of diets is presented in Table 1 . The protein in the diet for group I was derived entirely from egg white (freeze-dried) while in the diet for groups II and III, from $70 \%$ of egg white and $30 \%$ UDP, obtained from DG123 or DG153, respecitvely. The crude fibre content was complemented by cellulose (Whatmann CF11). The daily feed allowance was $10 \mathrm{~g}$ of a diet per rat.

The protein digestibility of these three diets was estimated using the Thomas-Mitchell balance method as modified by Eggum (1973). A 4-day adaptation period was followed by a 4-day total faecal and urine collection. 
TABLE 1

Composition of diets for rats (\%)

\begin{tabular}{lccc}
\hline & Group I & Group II & Group III \\
\hline Dried egg white & & & \\
Dehydrated grass, DG 1232 & 10.4 & 7.3 & 7.3 \\
Dehydrated grass, DG 1532 $^{2}$ & - & 30.3 & - \\
Cellulose & - & - & 23.7 \\
Wheat starch & 15.8 & 30.4 & 3.1 \\
Sucrose & 41.8 & 20.0 & 20.0 \\
Soya bean oil & 20.0 & 6.0 & 6.0 \\
Mineral mixture & 6.0 & 4.0 & 4.0 \\
Vitamin mixture & 4.0 & 2.0 & 2.0 \\
\hline In the diet: & 2.0 & & \\
Crude protein & & 10.0 & 10.0 \\
Crude fibre & 10.0 & 15.8 & 15.8 \\
\hline
\end{tabular}

1 Lyophilized

2 After incubation in the rumen

${ }^{3}$ Composition from Eggum (1973)

Throughout the experiment the rats were kept in individual metabolic cages.

The apparent and true digestibility of UDP in groups II and III were calculated assuming that the digestibility of egg white found for group I was the same as for groups II and III.

\section{Chemical analysis}

Samples of DG before and after incubation in the rumen, the diets for rats, faecal and urine samples were analyzed for dry matter, crude protein and crude fibre by standard methods (AOAC, 1975). ADIN was determined by the Van Soest method (Goering et al., 1970).

Statistical analysis

The results obtained for dry matter and protein degradability in the rumen and digestibility of UDP in rats were subjected to analysis of variance.

\section{RESULTS}

Dehydrated grasses (DG) did not differ in dry matter and protein contents (Table 2), but DG153 had a significantly higher proportion of ADIN in total $N(23.91 \%)$ than DG123 $(10.46 \%)$. Incubation in the rumen for 12 hours 
TABLE 2

Chemical composition of dehydrated grasses before and after incubation in the rumen (\%)

\begin{tabular}{lcccc}
\hline & $\begin{array}{c}\text { Dry } \\
\text { matter }\end{array}$ & $\begin{array}{c}\text { Crude } \\
\text { protein }\end{array}$ & $\begin{array}{c}\text { Crude } \\
\text { fibre }\end{array}$ & $\begin{array}{c}\text { ADIN } \\
\% \mathrm{~N}\end{array}$ \\
\hline $\begin{array}{l}\text { Before incubation } \\
123^{\circ} \mathrm{C}^{1}\end{array}$ & 93.36 & 16.06 & - & 10.46 \\
$153^{\circ} \mathrm{C}$ & 96.19 & 15.12 & - & 23.91 \\
\hline After incubation & & & & \\
$123^{\circ} \mathrm{C}$ & & 9.87 & 52.16 & - \\
$153^{\circ} \mathrm{C}$ & 98.53 & 12.69 & 53.39 & - \\
\hline
\end{tabular}

$123^{\circ} \mathrm{C}, 153^{\circ} \mathrm{C}-$ outflow temperature of the dryer

2 For 12 hours

decreased crude protein contents, particularly in DG123. Degradability of protein (Table 3) was significantly lower in DG153 (34.6\%) than in DG123 $(39.8 \%)(\mathrm{P}<0.01)$. On the other hand, there were no differences in dry matter degradability.

TABLE 3

Dry matter and protein degradability in the rumen of sheep after 12 hours of incubation in the rumen

\begin{tabular}{lccc}
\hline & \multicolumn{3}{c}{ Temperature } \\
& $123{ }^{\circ} \mathrm{C}$ & $153{ }^{\circ} \mathrm{C}$ & Significance level \\
\hline Dry matter & 35.2 & 36.4 & $\mathrm{P}>0.05$ \\
Crude protein & 39.8 & 34.6 & $\mathrm{P}<0.01$ \\
\hline
\end{tabular}

The results (Table 4) show that compared to group I, diets containing $30 \%$ UDP (group II and III) resulted in lower protein digestibility. However, when UDP digestibility was calculated (Table 5), both apparent and true digestibility of UDP coming from DG153 (88.0 and $92.6 \%$ ) were significantly higher than for DG123 (85.7 and $90.5 \%)$.

TABLE 4

Apparent and true digestibility of protein in diets for rats

\begin{tabular}{lccc}
\hline & Group I & Group II & Group III \\
\hline Apparent digestibility & 99 & 95.5 & 96.2 \\
True digestibility & 100 & 97.0 & 97.7 \\
\hline
\end{tabular}


Apparent and true digestibility of rumen undegraded dietary protein in rats

\begin{tabular}{lccc}
\hline & Temperature & Apparent digestibility & True digestibility \\
\hline $123^{\circ} \mathrm{C}$ & 85.7 & 90.5 \\
$153^{\circ} \mathrm{C}$ & 88.0 & 92.6 \\
Significance level $(\mathrm{P})$ & 0.029 & 0.013 \\
\hline
\end{tabular}

\section{DISCUSSION}

The new protein evaluation systems for ruminants require data on intestinal digestibility of undegraded dietary protein for different types of feeds. This is particularly important when using feeds which were chemically or heat treated to protect protein against degradation in the rumen. Excessive protection can considerably depress intestinal digestibility of amino acids, particularly of lysine.

In the present study the effect of different temperatures imposed on grass during dehydration $\left(123\right.$ vs. $\left.153^{\circ} \mathrm{C}\right)$ on protein degradability in the rumen and subsequent digestibility in the intestines was determined. Assuming that protein digestion processes in non-ruminants are generally similar to those occurring in the abomasum and small intestine of ruminants (Owens et. al., 1988), protein digestibility observed in rats will be considered here as equivalent to intestinal digestibility in ruminants.

The experimental feeds differed significantly in ADIN content in total N, considered to be an indicator of protein heat damage. A higher ADIN content, as a result of higher temperature, may be the main reason for the lower protein degradability in DG153, which is in line with other observations on decreasing rumen degradability as the result of heat treatment (Satter, 1986; Faldet et al., 1992; Kowalski et al., 1992).

For both DG, protein degradability was lower than that observed in our earlier experiment when the same feeds were tested using a standard in sacco procedure (Kowalski et al., 1992). The explanation is not yet clear but this could be either due to a possible contamination of feed residues by microbes, since a large sample is likely to be more difficult to wash out, or to a different 'movement' of the bigger bags $(18 \times 17 \mathrm{~cm})$ in the rumen.

Residues in the bags after rumen incubation were treated as samples of UDP, which then accounted for $30 \%$ of the protein content in the diets for rats. Apparent and true digestibility of UDP in rats were calculated taking into account $100 \%$ digestibility of egg white received in group I. The same digestibility of protein was observed by Storm (1982), when he infused egg white into the abomasum of sheep.

Higher temperature caused a slight but significant increase in digestibility of 
UDP. It seems that some of the protein which was protected against degradation by microbes in the rumen can be effectively digested in the intestine.

The true digestibility of UDP (over $90 \%$ ) determined in rats is higher than that proposed in the French system for dehydrated forages, i.e. $70 \%$ (Vérite et al., 1989). Other systems do not specify it but assume a constant value for all feeds between 0.8 and 0.9 (Hvelplund et al., 1990). The value found in this study also exceeds those found for most protein supplements (Hvelplund, 1985; De Boer et al., 1987; Peyraud et al., 1988). On the other hand, Hvelplund et al. (1980) suggest that because of a higher fibre content, UDP digestibility of forages should be lower than that of protein supplements. The reason for such a high digestibility in rats in this study is not clear, particularly taking into account the relatively high ADIN content in DG. This cannot be due to the contamination of UDP by microbes since intestinal digestibility of microbial protein itself is accepted as $80-85 \%$. These discrepancies should be explained in further experiments on a wider range of feeds.

\section{CONCLUSIONS}

It can be concluded that in spite of a high ADIN content, protein of dehydrated grass produced at 123 and $153^{\circ} \mathrm{C}$ (dryer outflow temperature) can be effectively utilized in the rumen and intestines. More research is needed to confirm the usefulness of rats in determining UDP digestibility.

\section{REFERENCES}

Agricultural Research Council, 1984. Report of the protein group of the Agricultural Research Council Working Party on The Nutrient Requirements of Ruminants. Commonwealth Agric. Bureau, pp. 45

Association of Official Analytical Chemists, 1975. Official Methods of Analysis of the Association of Official Analytical Chemists. 12th ed. Association of Official Analytical Chemists. Washington DC

De Boer G., Murphy J.J., Kennelly J.J., 1987. Mobile nylon bag for estimating intestinal availability of rumen undegradable protein. J. Dairy Sci. 70, 977-982

Eggum B.O., 1973. A study of certain factors influencing protein utilization in rats and pigs. Beret. Forsoegslab. Statens Husdyrbrugsudvalg, 406, 17-30

Faldet M.A., Satter L.D., Broderick G.A., 1992. Determining optimal heat treatment of soybeans by measuring available lysine chemically and biologically with rats to maximize protein utilization by ruminants. J. Nutr. 122, 151-160

Goering H.K., Van Soest P.J., 1970. Forage fiber analysis. Agric. Handbook 379, U.S.D.A.

Hvelplund T., 1985. Digestibility of rumen microbial protein and undegraded dietary protein estimated in the small intestine of sheep and by in sacco procedure. Acta Agric. Scand., Suppl. $25,132-144$

Hvelplund T., Madsen J., 1990. A study on the quantitative nitrogen metabolism in the gastro-intestinal tract, and the resultant new protein evaluation system for ruminants. The AAT-PBV system. Institute of Anim. Sci., The Royal Veterinary and Agricultural University, Copenhagen 
Hvelplund T., Weisbjerg M.R., Andersen L.S., 1992. Estimation of the true digestibility of rumen undegraded dietary protein in the small intestine of ruminants by the mobile bag technique. Acta Agric. Scand., Sect. A. Anim. Sci. 42, 34-39

Kowalski Z.M., Kamiński J., 1992. The effect of outflow temperature of the dryer on dehydrated grasses and alfalfa dry matter and protein degradability in the rumen. Acta agr. silv. Ser. Zoot., 30 (in press) (in Polish)

NKJ, 1985. Introduction of the Nordic protein evaluation system for ruminants into practice and further research requirements. Acta Agric. Scand., Suppl. 25, 216-220

Owens F.N., Zinn R., 1988. Protein metabolism in ruminant animals. In: D.C.Church (Editor), The Ruminant Animal. Digestive Physiology and Nutrition. Prentice Hall. 227-249

Peyraud J.L., Genesi-Rulquin Ch., Vérité R., 1988. Mesure de la digestion de l'azote des aliments dans l'intestin des ruminants par la technique des sachets mobiles. 2. Comparison de differents criteres de la teneur en azote reellement non digestible. Reprod. Nutr. Dévelop. 28, Suppl. 1, $131-132$

Satter L.D., 1986. Symposium: Protein and fibre digestion, passage and utilization in lactating cows. J. Dairy Sci. 69, $2734-2749$

Storm E., 1982. Isolation and nutritive value of rumen micro-organisms and their limiting amino acids for growing sheep. PhD Thesis, University of Aberdeen

Vérité R., Peyraud J.L., 1989. Protein: The PDI system. In: R. Jarrige (Editor), Ruminant Nutrition. INRA. $33-47$

\section{ACK NOWLEDGEMENTS}

The authors wish to thank Miss Beata Szymczyk from the Institute of Animal Science, Balice, Poland, for her technical assistance.

\section{STRESZCZENIE}

Próba oszacowania wpływu temperatury suszenia traw na strawność rzeczywistą białka za pomocą testu na szczurach

Badano wpływ temperatury wylotowej suszarni bębnowej $\left(123^{\circ} \mathrm{i} 153^{\circ} \mathrm{C}\right)$ na rozkład białka suszów $z$ traw w żwaczu oraz strawność przez szczury białka nie ulegającego rozkładowi w żwaczu (BNR $\dot{z}$ ). Za BNR $_{\dot{z}}$ przyjęto białko jakie pozostało po 12-godzinnej inkubacji prób $w$ żwaczu owiec. Doświadczenie strawnościowe wykonano na szczurach żywionych dawkami, w których białko BNR $_{\dot{z}}$ stanowiło $30 \%$, a bialko jaja kurzego $70 \%$.

Analizowane susze różniły się znacznie zawartością ADIN w stosunku do $\mathrm{N}$ ogólnego $\left(123^{\circ} \mathrm{C}\right.$ $-10,46 \%$ i $153^{\circ} \mathrm{C}-23,91 \%$ białka). Wyższa temperatura spowodowala również zmniejszenie rozkladu bialka $w$ żwaczu oznaczonego metodą in sacco $(0,35$ i 0,$40 ; \mathrm{P}<0.01)$. Strawność pozorna

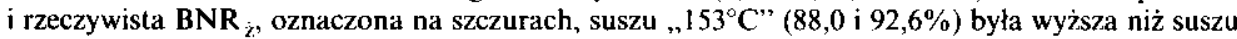
, $123^{\circ} \mathrm{C} "(85,7 \mathrm{i} 90,5 \%)$, co świadczyłoby o braku ujemnego wplywu temperatury $153^{\circ} \mathrm{C}$ na wykorzystanie bialka. 